\title{
The Formation Factors of Digital Literacy for Builiding Parents Competences
}

\author{
Iwan Hermawan $^{\mathrm{a}}$, Yossi Novila Sari ${ }^{\mathrm{a}}$, Rina Windiarti ${ }^{\mathrm{b}}$, Inayah Inayah \\ ${ }^{a}$ Politeknik Negeri Semarang, Semarang, Indonesia \\ ${ }^{\mathrm{b}}$ Universitas Negeri Semarang, Semarang, Indonesia \\ e-mail: iwanhermawan@polines.ac.id
}

\begin{abstract}
This research discusses about the building factors of digital literacy competentses for parents. The sample of this research were 45 correspondences, using a random sampling method. This research shows the forming factors of digital literacy on parents by using multivariate approach in the form of factor analysis on parents which resulted in the scientific fact that there were three forming factors of digital literacy on parents. The first factor consists of interaction with gadgets ( 0.615 loading factor), downloading applications in the gadgets (0.67 loading factor), using Internet Explorer to find information (0.611 loading factor), using social media as a discussion platform (0.704 loading factor), using all of the applications (0.578 loading factor), using a Personal Hotspot ( 0.639 loading factor). Those first six factors will be called the capability of using gadgets and internet factors. The second factor consists of assistance in using gadgets ( 0.861 loading factor) which will be called the time availability to assist in accessing information. The third factor consists of digital literacy factors $(-0.574$ loading factor) and choosing educative websites for children $(0.772$ loading factor) which will be called the selection of quality literacy contents. Based on the result of the Paired Sample T-Test with the significance level of 0.000 , there is a significant difference between before and after Parenting Program was executed, which was 11.8368.
\end{abstract}

Keywords: Parents, digital literacy, parenting program

\section{INTRODUCTION}

Information and technology development on the past few years have been increasing rapidly, its existence has a tremendous impact on creating a national generation that is superior and competitive to follow the ever-increasing digital literacy around us. Altogether, there is a nation-wide initiative that is promoting the education of technology, but the absorption level in schools is still very low (Sergis, et al., 2015). The optimization of competitive superiority opportunity is built by technological resources on source area including data, application system, infrastructure, and manpower. Technology will help develop the understanding on the core problem and reduce the cost of infrastructure (Hermawan, 2011). The education development on the digital era is rapidly expanding so it needs to be taken seriously, mastered, and controlled so that the digital era can bring benefits to children education, where the selection of information in good contents will bring the same push on good behavior on children. (Inayah et al 2017)

Within the last decade, the structure and function of internet has become unclear to the users and new digital social dimension that is growing exponentially, caused by the new and strong protocol that will lead and, most importantly, is progressive on losing contents in digital literacy. (Cartelli, A et al, 2015)

In education, the effort towards increasing the use of computer in all aspects of study needs to be increased for all generations to be sensitive about the currently developing technology (Gani, A. W. I., et 
al, 2006) . Technological and educational integrating has become very crucial. To effectively integrate technology and children education, the government needs to take the role of advocating the superiority of technology, because of that, develop a stance towards technology in its practice of education. Furthermore, the feedback needs to be collected in order to interpret technology continually (Jimmi, 2015). The educators' motivation is the most important thing in executing technology-based education; in this case, training the educators to effectively use technology is a crucial aspect. The educators' capabilities are not only how to apply technology in the teaching process but also knowing on how to include it in their daily lives (Norhayati, 1995). However, there are extrinsic obstacles in the practice of digital literacy, including the lack of resources, limited time, the lack of technical support, or the absence of the access to appropriate trainings. There are also intrinsic obstacles which include religious beliefs and individual moral values (Marsh, et al, 2017). The relationship between those extrinsic and intrinsic factors influences the use of digital technology in children education. The attitude towards the value of technology to help the children education process has the strongest influence in the use of technology, confidence, and support in using technology (Blackwell, et al., 2014)

The currently available technology in children education today has flaws, including the professional attitude of the educators in using technology, which shows the varying level of knowledge and experience (Fenty, 2014). To limit those flaws, a solution has been made on children education in the digital era, it is called a parenting immune selfer model. A parenting immune selfer model is a child assistance model that is effective, especially in a parenting which uses gadgets. It is crucial to give immune system to children because parents cannot be with them all the time. Parents should develop self-selective attitude on children, for example on which information is safe and what kind of news children are allowed to access (Setiawan, 2017). According to Gilster, which was quoted by A'yuni, Q. Q. (2015), digital literacy is the ability to understand and use information in various formats. Not only read, but also understand. The direction to which this research is to understand the formation factors of digital literation for buliding parents competences

understand the forming factors of digital literacy on parents.

\section{METHOD}

The population of digital literacy with parents who give formal education to children in Kudus, especially in PAUD Permata Bunda, will be the correspondence of this research. Sampling was done to gather an image of the total population. This research is a case study about the forming factors of digital literacy on parents. The list of questions are shown on the table below:

Table 1. Research Indicators

\begin{tabular}{ll}
\hline \hline No. & \multicolumn{1}{c}{ Research Indicators } \\
\hline 1 & $\begin{array}{l}\text { The presence of digital literacy information to } \\
\text { parents }\end{array}$ \\
2 & $\begin{array}{l}\text { Availability of hp / tablet / laptop / computer } \\
\text { (gadget / device) for parents }\end{array}$ \\
3 & $\begin{array}{l}\text { Availability of application downloads in parent } \\
\text { gadget }\end{array}$ \\
4 & $\begin{array}{l}\text { The availability of browser applications such as } \\
\text { Chrome / Mozilla Firefox / Internet Explorer for } \\
\text { parents as a means of information retrieval }\end{array}$ \\
5 & $\begin{array}{l}\text { Availability of social media for parents as a means } \\
\text { of discussion forum }\end{array}$ \\
6 & $\begin{array}{l}\text { The ability of parents to operate all gadget } \\
\text { applications }\end{array}$ \\
7 & $\begin{array}{l}\text { The fulfillment of personal hotspots for parents as } \\
\text { a means of supporting internet access }\end{array}$ \\
8 & $\begin{array}{l}\text { Selection of educative sites by parents for children. } \\
9\end{array}$ \\
\hline
\end{tabular}

The primary data that is used to reveal the facts in his research was obtained though observation using questionnaires and controlled by interviews to parents. The analysis tool in this research is factor analysis. To put it simply, factor analysis is used to determine how many factors (variables) there is to obtain a multivariate with enough components that can be explained and simplified to be several chosen factors.

Factor analysis model:

$$
\begin{aligned}
& X_{i k}=\lambda_{i 1} f_{1 k}+\lambda_{i 2} f_{2 k}+\ldots \ldots+\lambda_{i 2} f_{2 k}+e_{i k} \\
& \boldsymbol{X}_{\boldsymbol{i} \boldsymbol{k}}=\text { value from } \mathrm{i} \text { variable to observation }
\end{aligned}
$$
factor, where there is $\mathrm{m}$ factor and $\mathrm{p}$ variable, $\mathrm{m}<\mathrm{p}$ 


\section{RESULT AND DISCUSSION}

The discussion in this paper is to find a scientific fact about the forming factors of digital literacy on parents. Where there is an continuous attraction towards the ability to use digital technology to access data as well as look up information in each individual, especially parents.

This then needs a digital literacy capability measurement on parents. The data on information factor capability, gadgets, applications downloading, search engine applications, social medias, gadgets operation, Personal Hotspot, educative sites, and assistance of the capability frame from parents who give formal education assistance to kids who live in Kudus.

Table 2. KMO and Bartlett's Test

\begin{tabular}{ll}
\hline \hline Test & Value \\
\hline $\begin{array}{l}\text { Kaiser-Meyer-Olkin Measure } \\
\text { of Sampling Adequacy. }\end{array}$ & 0.595 \\
Bartlett's Test of Sphericity & \\
Approx. Chi-Square & 75.302 \\
Df & 36 \\
Sig. & 0 \\
\hline \hline
\end{tabular}

The result of anti-image correlation above is 0.5 . This shows that all variables is worthy of factor analysis. Adequacy sample test was done through Kaiser Meyen Olkin Measure of Sampling Adequacy (KMO), the value of $\mathrm{KMO}$ is 0.595 bigger than 0.5 . this means that the sample taken is enough to be analyzed. The number of Bartlett's test (shown on the chi-square) is 75.302 with a significance value of 0.000 . This shows that the correlation matrix is not an identity matrix, so it can be put in the model

\begin{tabular}{ccrrrrr}
\multicolumn{3}{l}{ Table 3. Rotated Component Matrix } \\
\hline \hline Components & \multicolumn{2}{c}{ Initial Eigenvalues } & \multicolumn{4}{c}{ Extraction Sums of Squared Loadings } \\
& Total & Variance & Comulative & \multicolumn{1}{c}{ Total } & Variance & Comulatif \\
\hline 1 & 2.743 & 30.475 & 30.475 & 2.743 & 30.475 & 30.475 \\
2 & 1.425 & 15.828 & 46.304 & 1.425 & 15.828 & 46.304 \\
3 & 1.182 & 13.135 & 59.439 & 1.182 & 13.135 & 59.439 \\
4 & 0.959 & 10.659 & 70.097 & & & \\
5 & 0.761 & 8.46 & 78.557 & & & \\
6 & 0.646 & 7.172 & 85.73 & & & \\
7 & 0.554 & 6.156 & 91.885 & & & \\
8 & 0.444 & 4.932 & 96.817 & & & \\
9 & 0.286 & 3.183 & 100 & & & \\
\hline \hline Extraction Method: Principal Component Analysis.
\end{tabular}

From the result of factor analysis based on Eigen value of one or bigger, on the Total Variance Explained table above, there are 3 factors formed by 9 variables that are put in. The total percentage value for all three factors are 59.439, which means all three factors can explain the multivariate data that is 9 more variables than 0.5 .

\section{Table 4. Rotated Component Matrix Digital Literacy}

\begin{tabular}{lrrr}
\hline \multirow{2}{*}{ Digital Literacy Capability } & \multicolumn{3}{c}{ Factor Components } \\
& \multicolumn{1}{c}{1} & \multicolumn{1}{c}{2} & \multicolumn{1}{c}{3} \\
\hline Digital literacy information & 0.441 & 0.517 & -0.574 \\
Interactions with gadgets & 0.615 & -0.38 & -0.223 \\
Download apps in the gadget & 0.67 & 0.032 & 0.358 \\
Use Internet Explorer to search for & 0.611 & 0.324 & 0.021 \\
information & & & \\
Social media for discussion & 0.704 & -0.344 & 0.074 \\
Operate all apps & 0.578 & -0.151 & -0.258 \\
Using Personal Hotspot & 0.639 & 0.017 & -0.033 \\
Select an educative site for children & 0.325 & 0.155 & 0.772 \\
Accompany when using gadgets & 0.063 & 0.861 & 0.071 \\
\hline \hline
\end{tabular}

The Rotated Component Matrix above shows the forming of three factors, with the first factor group including: a) interactions with gadget (0.615 loading factor); b) download applications in the gadgets (0.67 loading factor); c) use Internet Explorer to search for information (0.611 loading factor); d) Social media for discussion (0.704 loading factor); e) operate all applications (0.578 loading factor); f) using Personal Hotspot (0.639 loading factor) in this research will be called the six factors of gadget and internet capability.

The second group of factors consists of only one factor, which is the accompany when using gadgets (0.861 loading factor) in this research will be called the time availability on assistance in accessing information.

The third group of factors consists of two factors, including: a) digital literacy information (0.574 loading factor); b) choosing educative websites for children ( 0.772 loading factor) in this research both factors are information about digital literacy and the selection of educative sites for children in the selection of quality literacy content.

\begin{tabular}{lccccc}
\multicolumn{1}{l}{ Table 5. Paired Samples Statistics } \\
\hline \hline & Maen & N & $\begin{array}{c}\text { Std. } \\
\text { Deviasion }\end{array}$ & $\begin{array}{c}\text { Std. Error } \\
\text { Mean }\end{array}$ \\
\hline Pair 1 & Pre & 12.0816 & 49 & 2.8711 & 0.41016 \\
& Post & 23.9164 & 49 & 5.51451 & 0.78779
\end{tabular}

From the T-test above, it is shown that the pretest result (before parenting was executed) has an 
average number of 12.0816 ., while the posttest result (after parenting was executed) has an average number of 23.9164 .

\begin{tabular}{|c|c|c|c|c|c|c|c|c|}
\hline & \multirow[t]{2}{*}{ Mean } & \multirow[t]{2}{*}{$\begin{array}{c}\text { Std. } \\
\text { Deviasion }\end{array}$} & \multirow[t]{2}{*}{$\begin{array}{l}\text { Std. Error } \\
\text { Mean }\end{array}$} & \multicolumn{2}{|c|}{$\begin{array}{l}95 \% \text { Confidence Interval of } \\
\text { the Difference }\end{array}$} & \multirow[b]{2}{*}{$\mathrm{t}$} & \multirow{2}{*}{\multicolumn{2}{|c|}{$\begin{array}{l}\text { sig. (2 } \\
\text { tailed) }\end{array}$}} \\
\hline & & & & Lower & Upper & & & \\
\hline Pair 1 Pre-Post & -11.8367 & 2.65634 & 0.3794 & $8-12.5997$ & -11.0737 & -31.192 & 48 & 0 \\
\hline
\end{tabular}

Based on the Paired Samples T-test above, which stated before and after parenting was done, there is a significant difference because the result on sig (2-tailed) is 0.000 which shows that the number is less than 0.05 . It can then be concluded that there is an increase after parenting was done.

\section{CONCLUSION}

The formation factors of digital literation for buliding parents competences in this research were tested using factor analysis, resulting in three forming factors, which are gadgets and internet capability factor, time availability for information access assistance, and selection of quality literacy content. After going through the Paired Sample Ttest, it was proved that there is a difference between before and after parenting, which is 11.8368 .

\section{RESEARCH LIMITATIONS}

This research is limited only for PAUD Permata Bunda Kudus, so within this limitation, it needs to compares and confirms by replacing this research in a wider sample area to obtain a whole description model in the future.

\section{IMPLICATION}

The forming factors of digital literacy in this paper include the gadgets and internet capability factor, time availability for information access assistance, and selection of quality literacy content. The implication of gadget and internet capability is a must-have competence for parents, along with the development of technology. Parents must follow the ever-growing trend and the popular applications. Furthermore, another important aspect is for parents to spend time with their children in accessing educative information and explain the meaning and the wisdom in the digital literacy content. Moreover, to sort and make a priority scale on the appropriate literacy content for children.
The result of the Paired Sample T-test is 0.000, which shows that there is a difference between before and after parenting. This gives a description of the strategic value on parenting approach in forming a digital literacy competence on parents, so that the effect can be a support for parents in forming digital literacy competence.

\section{ACKNOWLEDGEMENT}

We would like to thank the Ministry Of Research for funding this research on the forming factors of digital literacy on parents, P3M Politeknik Negeri Semarang for managing the research from the start until it was done, thank you for the students of Business Administration and department of Early Childhood and Teacher Education Universitas Negeri Semarang for giving observational support so that the outputs worked out well.

\section{REFERENCES}

[1] Abdul Wahab Ismail Gani, Kamaliah Hj. Siarap \& Hasrina Mustafa. 2006. Penggunaan komputer dalam pengajaran-pembelajaran dalam kalangan guru sekolah menengah: satu kajian kes di pulau Pinang. Kajian Malaysia, 24(1\&2)

[2] A'yuni, Q. Q. (2015). Literasi digital remaja di kota Surabaya. Jurnal Fakultas Ilmu Sosial dan Ilmu Politik, Universitas Airlangga Surabaya.

[3] Blackwell, C.K., Lauricella, A.R., and Wartella, E. (2014). Factors influencing digital technology use in early childhood education. Computers \& Education 77 (0), pp. 82-90.

[4] Cartelli, A., Giovannella, C. (2015). Digital Literacy and Digital Competence: Facts, Problems, Needs \& Trends. Researchgate.

[5] Copriady, J. (2015). Elsevier Ltd. 176 ( 2015 ) $699-708$

[6] Fenty, N.S., and McKendry A.E.M. (2014). Examining Educators'Knowledge, Beliefs, and Practices About Using Technology With Young Children. Journal of Early Childhood Teacher Education, 35 (2), pp. 114-134.

[7] Hermawan, I. (2011). Profil Pembelajaran Inovatif Kurikulum PBE Pada Mata Kuliah Berbasis Proyek Melalui Pengembangan Perangkat Lunak Multimedia. Jurnal TIK Provisi, 2(1).

[8] Inayah, Inayah et al. Model Pembangunan Karakter Inspiratif dan Humanis Tokoh Utama Kartun pada Game Antikorupsi Menggunakan Pendekatan MBTI Briggs Mayer. Prosiding Sentrinov (Seminar Nasional Terapan Riset Inovatif), [S.1.], v. 3, n. 1, p. PD65-PD77, nov. 2017. ISSN 2477-2097.

[9] Marsh, J.,Kontovourki, S., Tafa, E.,Salomaa, S. (2017) Developing Digital Literacy in Early 
Years Settings: Professional Development Needs for Practitioners. COST Action IS1410.

[10] Norhayati Abd Mukti, (1995). Factors related to teacher use of computer technology in Malaysia. Doctoral Dissertation: Michigan State University
[11] Setiawan, W. (2017). Era Digital dan Tantangannya. Seminar Nasional Pendidikan. Repositori UMMI

[12] Sergis, S., Zervas, P. \& Sampson, D. (2015). A holistic approach for managing School ICT Competence Profiles towards supporting schoo ICT uptake. International Journal of Digital Literacy and Digital Competence, vol. 5 (4), 